PAULINA CZERNIGA-PUK,

Fundacja Instytut Psychologii i Psychoterapii Proaktywnej proPORT w Poznaniu, Uniwersytet Medyczny im. Karola Marcinkowskiego w Poznaniu

TOMASZ JUŃCZYK

Fundacja Instytut Psychologii i Psychoterapii Proaktywnej proPORT w Poznaniu

\title{
SZKOLNY KONTEKST PSYCHOLOGII POZYTYWNEJ. STUDIUM EMPIRYCZNE
}

\begin{abstract}
Czerniga-Puk Paulina, Juńczyk Tomasz, Szkolny kontekst psychologii pozytywnej. Studium empiryczne [Educational Context of Positive Psychology. An Empirical Study]. Studia Edukacyjne nr 37, 2015, Poznań 2015, pp. 237-256. Adam Mickiewicz University Press. ISBN 978-83-232-2967-4. ISSN 1233-6688. DOI: 10.14746/se.2015.37.14

Previous research on the effects of techniques of positive psychology on students' psychological welfare and school grades bring very promising results. The authors decided to test the hypothesis of the impact of students' attributional style on their grades in mathematics. For this purpose, a pilot study was conducted on a group of 68 students of lower secondary school. The results partially support the hypotheses tested. The article also provides a catalog of practical methodical recommendations for teachers. These recommendations have been implemented practically in educational context and its effectiveness have been proven.
\end{abstract}

Key words: positive psychology, attributional styles, lower secondary school

\section{Wprowadzenie}

Od edukacji matematyczno-przyrodniczej, poprzez edukację ekologiczną, na rozwoju społeczeństwa obywatelskiego kończąc, nauczyciele stają przed koniecznością przekazywania uczniom ogromnego zasobu wiedzy, kształtowania ich kompetencji i rozwijania umiejętności w bardzo różnych obszarach tematycznych. W opinii autorów artykułu, jedno z najbardziej uniwersalnych pytań, jakie stawiają sobie współcześni nauczyciele brzmi: Jak zmotywować ucznia do nauki, aby ten osiągnął edukacyjny sukces? Pytanie to staje się tym bardziej istotne, im większy i trudniejszy jest zakres 
materiału przekazywanego uczniowi $\mathrm{w}$ procesie edukacji. $\mathrm{W}$ obrębie psychologii pozytywnej, której założenia stanowią fundament teoretyczny niniejszego artykułu, badacze przeprowadzili setki badań empirycznych, m.in. na temat zależności pomiędzy profilem psychologicznym ucznia, jego procesami motywacyjnymi, modelem komunikacji na linii uczeń-nauczyciel a ocenami szkolnymi. Na podstawie tychże badań opracowano katalog wysoce praktycznych rekomendacji edukacyjnych dla nauczycieli, których zastosowanie przyczynia się do poprawy zarówno psychologicznych aspektów funkcjonowania ucznia w szkole (np. obniżenie poziomu agresji wobec nauczycieli), jak i poziomu ocen z poszczególnych przedmiotów kształcenia.

Celem artykułu jest prezentacja podstawowych założeń teoretycznych psychologii pozytywnej, wyników pilotażowych badań empirycznych przeprowadzonych przez autorów oraz metodologicznych zaleceń dla nauczycieli.

\section{Styl atrybucji w psychologii pozytywnej}

Styl atrybucji to sposób, w jaki jednostka reaguje na doświadczane wydarzenia, zarówno te, które definiuje jako porażki, jak i te definiowane jako sukcesy. „Reakcja” w modelu poznawczym stylu atrybucji oznacza sposób wytłumaczenia sobie przyczyn tych zjawisk w trzech aspektach: ich stałości, zasięgu oraz personalizacji1. Pierwotnie koncepcja "stylów atrybucji” została zaproponowana przez Martina Seligmana i współpracowników jako wyjaśnienie przyczyn depresji², jednak okazała się bardzo inspirująca i zaczęto wykorzystywać ją jako fundament teoretyczny do wyjaśniania wielu innych zjawisk (np. sukcesów edukacyjnych uczniów). Martin Seligman ostatecznie wyróżnił optymistyczny i pesymistyczny styl atrybucji, będący czynnikiem różnicującym w obrębie populacji ${ }^{3}$. Charakterystykę obu stylów atrybucji prezentuje tabela 1.

${ }^{1}$ L. Caimei, T.C. Bates, The structure of attributional style: Cognitive styles and optimismpessimism bias in the Attributional Style Questionnaire, Personality and Individual Differences, 2014, 66, s. 79.

2 L.Y. Abramson, M.E.P. Seligman, J.D. Teasdale, Learned Helplessness in Humans: Critique and Reformulation, Journal of Abnormal Psychology, 1978, 87, 1, s. 49-74.

${ }^{3}$ M.E.P. Seligman, Optymizmu można się nauczyć. Jak zmienić swoje myślenia i swoje życie, przekł. Andrzej Jankowski, Poznań 2002. 
Tabela 1

Styl atrybucji w odniesieniu do porażek i sukcesów

\begin{tabular}{|c|c|c|c|}
\hline $\begin{array}{c}\text { STYL } \\
\text { ATRYBUCJI }\end{array}$ & $\begin{array}{c}\text { CZYNNIKI } \\
\text { W RAMACH } \\
\text { STYLU } \\
\text { ATRUBUCJI }\end{array}$ & $\begin{array}{c}\text { WYJAŚNIENIE } \\
\text { (ATRYBUCJE) } \\
\text { W SYTUACJACH } \\
\text { POWODZE- } \\
\text { NIA/SUKCESU } \\
\end{array}$ & $\begin{array}{l}\text { WYJAŚNIENIA } \\
\text { (ATRYBUCJE) } \\
\text { W SYTUACJACH } \\
\text { NIEPOWODZE- } \\
\text { NIA/PORAŻKI }\end{array}$ \\
\hline \multirow{3}{*}{$\begin{array}{l}\text { PESYMI- } \\
\text { STYCZNY }\end{array}$} & STAŁOŚĆ & $\begin{array}{l}\text { To przypadek, że tak } \\
\text { wyszło; miałem/miałam } \\
\text { wyjątkowo dobry dzień } \\
\text { i tylko dlatego się udało; } \\
\text { ten sukces pewnie się nie } \\
\text { powtórzy, itp. } \\
= \\
\text { WYJAŚNIENIE } \\
\text { ZMIENNE }\end{array}$ & $\begin{array}{l}\text { Zawsze mnie spotykają takie } \\
\text { złe rzeczy; nigdy nie może być } \\
\text { dobrze; to zawsze mi nie } \\
\text { wychodzi; matematyka nigdy } \\
\text { nie była moją mocną stroną, } \\
\text { itp. } \\
= \\
\text { WYJAŚNIENIE STAŁE }\end{array}$ \\
\hline & ZASIĘG & $\begin{array}{l}\text { Skoro nauczyłem się } \\
\text { mnożenia, to wcale nie } \\
\text { oznacza, że nauczę się } \\
\text { pierwiastków; im dalej } \\
\text { z materiałem, tym pew- } \\
\text { nie będzie trudniej. } \\
= \\
\text { ZASIĘG OGRANICZO- } \\
\text { NY }\end{array}$ & $\begin{array}{l}\text { Jestem wykończony/a; mate- } \\
\text { matyka jest bardzo trudna; nie } \\
\text { mam już na nic siły, itp. } \\
= \\
\text { ZASIĘG NIEOGRANICZONY }\end{array}$ \\
\hline & $\begin{array}{c}\text { PERSONALI- } \\
\text { ZACJA }\end{array}$ & $\begin{array}{l}\text { To wynik przypadku, } \\
\text { losu, zbiegu okoliczno- } \\
\text { ści, czynników zewnę- } \\
\text { trznych. } \\
= \\
\text { PERSONALIZACJA } \\
\text { ZEWNĘTRZNA }\end{array}$ & $\begin{array}{l}\text { To moja wina, nie jestem } \\
\text { wystarczająco dobry, inteli- } \\
\text { gentny, itp. Przyczyną niepo- } \\
\text { wodzenia jestem ja sam/ja } \\
\text { sama. } \\
= \\
\text { PERSONALIZACJA WEWNĘ- } \\
\text { TRZNA }\end{array}$ \\
\hline \multirow{2}{*}{$\begin{array}{l}\text { OPTYMI- } \\
\text { STYCZNY }\end{array}$} & STAŁOŚĆ & $\begin{array}{l}\text { Z reguły osiągam to, co } \\
\text { sobie zaplanuję; udaje mi } \\
\text { się zdobywać cele; dzięki } \\
\text { ciężkiej pracy sukcesu są } \\
\text { osiągalne, itp. } \\
= \\
\text { WYJAŚNIENIE STAŁE }\end{array}$ & $\begin{array}{l}\text { Byłem przeziębiony/a dlatego } \\
\text { tak źle poszło; dziś miałem } \\
\text { gorszy dzień; w przyszłości } \\
\text { więcej będę się uczyl, więc } \\
\text { wyniki będą lepsze, itp. } \\
= \\
\text { WYJAŚNIENIE ZMIENNE }\end{array}$ \\
\hline & ZASIĘG & $\begin{array}{l}\text { Skoro udało mi się na- } \\
\text { uczyć mnożenia, to } \\
\text { pewnie z pierwiastkami } \\
\text { też sobie poradzę; udo- } \\
\text { wodniłem/am sobie, że } \\
\text { potrafię się nauczyć } \\
\text { trudnego materiału, więc }\end{array}$ & $\begin{array}{l}\text { Jestem zmęczony/a tą nauką; } \\
\text { nauka geometrii jest trudna; } \\
\text { dziś już nie mam siły na na- } \\
\text { ukę. } \\
= \\
\text { ZASIĘG OGRANICZONY }\end{array}$ \\
\hline
\end{tabular}




\begin{tabular}{|c|c|c|c|}
\hline \multirow[t]{3}{*}{$\begin{array}{c}\text { STYL } \\
\text { ATRYBUCJI }\end{array}$} & \multirow[t]{2}{*}{$\begin{array}{l}\text { CZYNNIKI } \\
\text { W RAMACH } \\
\text { STYLU } \\
\text { ATRUBUCJI }\end{array}$} & $\begin{array}{c}\text { WYJAŚNIENIE } \\
\text { (ATRYBUCJE) } \\
\text { W SYTUACJACH } \\
\text { POWODZE- } \\
\text { NIA/SUKCESU }\end{array}$ & $\begin{array}{c}\text { WYJAŚNIENIA } \\
\text { (ATRYBUCJE) } \\
\text { W SYTUACJACH } \\
\text { NIEPOWODZE- } \\
\text { NIA/PORAŻKI }\end{array}$ \\
\hline & & $\begin{array}{l}\text { w przyszłości też to } \\
\text { zrobię, } \\
\text { ZASIĘG } \\
\text { CZON. NIEOGRANI- }\end{array}$ & \\
\hline & $\begin{array}{c}\text { PERSONALI- } \\
\text { ZACJA }\end{array}$ & $\begin{array}{l}\text { To dzięki mojej ciężkiej } \\
\text { pracy, inteligencji, wy- } \\
\text { siłkowi, zaangażowaniu, } \\
\text { itp. Przyczyną sukcesu } \\
\text { jestem ja sam/ja sama. } \\
= \\
\text { PERSONALIZACJA } \\
\text { WEWNĘTRZNA }\end{array}$ & $\begin{array}{l}\text { To wynik przypadku, losu, } \\
\text { zbiegu okoliczności, czynni- } \\
\text { ków zewnętrznych, niefor- } \\
\text { tunnego zbiegu okoliczności. } \\
= \\
\text { PERSONALIZACJA ZEWNĘ- } \\
\text { TRZNA }\end{array}$ \\
\hline
\end{tabular}

Źródło: opracowanie własne na podstawie: L.Y. Abramson, M.E.P. Seligman, J.D. Teasdale, Learned Helplessness in Humans: Critique and Reformulation, Journal of Abnormal Psychology, 1978, 87, 1, s. 49-74.

Poniżej proponujemy syntetyczne zestawienie najważniejszych cech wymiarów stylów atrybucji.

1. Styl atrybucji kształtuje się średnio do 7-8 roku życiu. Oznacza to, że na jego strukturę wpływa głównie socjalizacja pierwotna oraz edukacja przedszkolna ${ }^{4}$. Na wyższych etapach edukacyjnych nauczyciele pracują z uczniami, którzy mają ukonstytuowany styl atrybucji. Jak jednak zostanie to zaprezentowane poniżej, odpowiednie działania edukacyjne mogą modyfikować istniejący styl atrybucji.

2. Uruchamianie się myśli (przekonań) związanych z określonym stylem atrybucji może przyjmować charakter automatyzmów ${ }^{5}$. Oznacza to, że wielokrotnie uczeń nie uświadamia sobie własnych przekonań na temat sukcesów i niepowodzeń, wzmacniając tym samym ich wpływ na procesy motywacyjne. Innymi słowy, im mniej uczeń zdaje sobie sprawę z mechanizmów, jakie kierują jego emocjami i zachowaniem, tym większy jest ich wpływ.

3. Każde przekonanie może zostać przeanalizowane w kontekście 3 wymiarów stylu atrybucji, tzn. może być ono stałe vs zmienne, o zasięgu ograniczonym vs zasięgu nieograniczonym, personalizowane wewnętrznie vs zewnętrznie. Na przykład: w sytuacji niepowodzenia szkolnego - niezdania egzaminu gimnazjalnego - uczeń może pomyśleć: „Nie nadaję się do

4 Tamże, s. 87.

${ }^{5}$ K.S. Dobson, D.J.A. Dozois, Historical and Philosophical Bases of the Cognitive-Behavioral Therapy, [w:] Handbook of Cognitve-Behavioral Therapies, red. K.S. Dobson, New York 2010, s. 14. 
nauki". Przekonanie to będzie miało charakter stały, o zasięgu nieograniczonym i personalizowane wewnętrznie. Wystarczy jedna niewielka zmiana w przekonaniu, np. „Nie umiem dobrze zdawać egzaminów”, by charakter przekonania stał się: stały, ograniczony i personalizowany wewnętrznie ${ }^{6}$.

4. Badania empiryczne wskazują, iż osoby, u których zdefiniowano w sytuacjach niepowodzenia wyjaśnienia (przekonania) o charakterze nieograniczonym (patrz ryc. 1) - np. "Nie mam już na nic siły”, "Nauka to nie dla mnie", "To jest ponad moje umiejętności”, ,Nie jestem mądry/mądra" itp. - będą uruchamiać w sobie skrypty tego rodzaju, także w sytuacjach nowych, niepodobnych do tych, w których ponieśli porażkę. Z kolei, jeśli osoba ma tendencję do przekonań dotyczących niepowodzeń o charakterze ograniczonym, wówczas przekonania tego typu będą się uruchamiać wyłącznie w sytuacjach podobnych do tej pierwotnej, w której osoba poniosła porażkę ${ }^{7}$. Niesie to ze sobą bardzo duże konsekwencje praktyczne, także w obszarze edukacji. Jeśli bowiem dziecko (uczeń) myśli o niepowodzeniach w kategoriach nieograniczonych, to wówczas porażka w jednym tylko obszarze merytorycznym będzie wystarczająca do powstania u ucznia przekonania, iż szansa na sukces edukacyjny jest niewielka lub wręcz żadna, czego konsekwencją będzie drastyczny spadek motywacji do podejmowania wysiłku. Na przykład, skrypt tego rodzaju spowoduje, iż uczeń, który poniósł porażkę (np. nie zdał sprawdzianu) z zakresu odejmowania i dodawania ułamków przełoży ją na całą matematykę, generując myśl automatyczną o brzmieniu: "Nie będę zdawał sprawdzianów z matematyki”, uczeń zaś o przeciwnym skrypcie (tj. o zasięgu ograniczonym) zawęzi zakres niepowodzenia do odejmowania i dodawania ułamków.

\section{Wyniki badań nad wpływem stylu atrybucji na sukcesy edukacyjne ucznia}

Dotychczas przeprowadzono setki badań na temat związków pomiędzy stylem atrybucji a różnymi aspektami funkcjonowania jednostki. Udowodniono m.in.: wprost proporcjonalny wpływ negatywnego stylu atrybucji uczniów na poziom ich wrogości oraz strachu ${ }^{8}$, dominację negatywnego

${ }^{6}$ L.Y. Abramson, M.E.P. Seligman, J.D. Teasdale, Learned Helplessness in Humans, s. 9.

7 L.B. Alloy i in., Attributional Style and the Generality of Learned Helplessness, Journal of Personality and Social Psychology, 1984, 46, 3, s. 681-687.

8 J. Ciarrochi, P.C.L. Heaven, F. Davis, The impact of hope, self-esteem, and attributional style on adolescents' school grades and emotional well-being: A longitudinal study, Journal of Research in Personality, 2007, 41, s. 1161-1178. 
stylu atrybucji u uzależnionych od narkotyków młodych mężczyzn oraz wpływ stylu atrybucji na skuteczność terapii leczących uzależnienia9, znaczenie pozytywnego stylu atrybucji dla uruchomienia się mechanizmów tzw. gorącego poznania (hot cognition), sprzyjających uczeniu się języków obcych $^{10}$, znaczenie stylu atrybucji dla samooceny dzieci oraz poziom ich nieśmiałości ${ }^{11}$, a nawet dla wydajności sportowej piłkarzy ${ }^{12}$. W obliczu niezliczonych badań (głównie amerykańskich) dotyczących siły stylu atrybucji trudno zaprzeczyć, że jest to czynnik istotnie wpływający na szeroko zdefiniowane sukcesy (na poziomie emocjonalnym, poznawczym, czy behawioralnym).

Od co najmniej kilku lat istotnym elementem polityki edukacyjnej państwa jest promowanie nauczania nauk matematyczno-przyrodniczych wśród polskich uczniów. W ramach chociażby funduszy europejskich wydatkowano ogromne środki na tworzenie innowacyjnych programów, technik, materiałów dydaktycznych, które miałyby zachęcić uczniów do zgłębiania tajników matematyki. Nie znaleźliśmy jednak żadnych wyników polskich badań, które podjęłyby temat znaczenia stylu atrybucji dla efektów edukacyjnych $\mathrm{w}$ obszarze matematyki właśnie. Okazuje się natomiast, że i tutaj występują znaczące korelacje: pesymizm w obszarze stylu atrybucji istotnie koreluje z ocenami z matematyki (im wyższy pesymizm, tym niższe osiągnięcia), także w perspektywie długoterminowej (trzyletniej) ${ }^{13}$. W kontekście powyższych badań pojawia się jedno zasadnicze pytanie: Skoro styl atrybucji koreluje z wieloma aspektami funkcjonowania uczniów, to czy wdrożenie programu nauczania opartego na modelu proponowanym przez Martina Seligmana i współpracowników w jakikolwiek sposób wpływa na ich zachowania i osiągnięcia szkolne w środowisku szkolnym?

W roku 2007 uruchomiono pierwszy kompleksowy program nauczania, włączający w swoje ramy merytoryczne podstawowe założenia psychologii pozytywnej. Realizowany jest on w Geelong Grammar School (GGS) w Australii. Po serii szkoleń dla nauczycieli oraz obsługi technicznej, w roku 2011

${ }^{9}$ F. Shaghaghy i in., The Relationship of Early Maladaptive Schemas, Attributional Styles and Learned Helplessness among Addicted and Non-Addicted Men, Addict \& Health, 2011, 3(1-2), s. 45-52.

10 R.L. Oxford, L. Cuéllar, Positive psychology in cross-cultural narratives: Mexican students discover themselves while learning Chinese, Studies in Second Language Learning and Teaching, 2014, 4(2), s. 173-203.

11 S.M. Chan, A.K.Y. Wong, Shyness in late childhood: relations with attributional styles and self-esteem, Child: Care, Health and Development, 2011, 39, s. 213-219.

12 R.A. Gordon, Attributional style and athletic performance: Strategic optimism and defensive pessimism, Psychology of Sport and Exercise, 2008, 9, s. 336-350.

13 S.M. Yates, The Influence of Optimism and Pessimism on Student Achievement in Mathematics, Mathematics Education Research Journal, 2002, 14, 1, s. 4-15. 
uruchomiono pierwszy cykl nauczania dla uczniów. Prezentowane poniżej wyniki pochodzą z pierwszego raportu ewaluacyjnego, opublikowanego w 2014 roku. Są one niezwykle inspirujące i warte uwagi w kontekście dbałości o jakość i skuteczność współczesnej edukacji. W grupie eksperymentalnej (objętej nowym programem nauczania), w porównaniu z grupą kontrolną, stwierdzono: niższy poziom wskaźników depresji, niższy poziom złości, wyższy wzrost deklarowanego poziomu zadowolenia z życia oraz dobrostanu, częstsze stosowanie rozwojowych strategii radzenia sobie z codziennymi sytuacjami. Wzrósł również poziom ocen z matematyki (w grupie 10i 11-latków) i języka angielskiego (w grupie 9-, 10- i 11-latków), tutaj jednak badacze są dalecy od wyciągania wniosków, że jest to zasługa programu opartego na psychologii pozytywnej w związku z brakiem grupy kontrolnej, jednakże jest to prawdopodobne ${ }^{14}$. Analiza wyników raportu pozwoliła badaczom z Uniwersytetu w Melbourne na rekomendowanie kontynuacji wdrażania programu. W dużo mniejszym zakresie przeprowadzono badania nad skutecznością programów nauczania włączających perspektywę psychologii pozytywnej w szkole w Izraelu, wśród uczniów w wieku 7-9 lat. $\mathrm{W}$ porównaniu $\mathrm{z}$ grupą kontrolną, $\mathrm{w}$ grupie eksperymentalnej znacząco obniżyły się syndromy dystresu, lęku, depresji, wzmocniła się samoocena oraz poczucie kompetencji15. W obu szkołach przyjęto całkowicie odrębne metody wdrażania psychologii pozytywnej. W GGS wsparcie ma charakter $\mathrm{w}$ pełni systemowy. Szkoleniem objęci są nauczyciele, rodzice, personel szkoły. W ramach programu wdrożono również system konsultacji, a w strukturze szkoły powołano Instytut Edukacji Pozytywnej. W założeniu program ma być wieloletni. W placówce izraelskiej przeprowadzono dla nauczycieli 15 dwugodzinnych sesji szkoleniowych, stworzono poradnik dla nauczycieli, część lekcji była wizytowana przez psychologów, w celu ich oceny i przekazania informacji zwrotnej edukatorom. Zakres był zatem znacznie mniejszy niż w GGS, a sam program trwał rok. W obydwu przypadkach rezultatem wdrożenia miało być prowadzenie przez nauczycieli zajęć $\mathrm{w}$ ramach swoich przedmiotów z uwzględnieniem zasad i technik psychologii pozytywnej. Przedstawione doświadczenia dwóch diametralnie różnych placówek edukacyjnych wskazują, że dzięki wdrożeniu zmian, nie tyle w merytorycznej części zajęć, ale w ich warstwie metodycznej możliwe jest osiągnięcie wyników co najmniej satysfakcjonujących w obszarze samooceny i motywacji ucznia.

${ }^{14}$ D.A. Vella-Brodrick, N.S. Rickard, T-C. Chin, An Evaluation of Positive Education at Geelong Grammar School: A Snapshot of 2013, Melbourne 2014.

15 A. Shoshani, S. Steinmetz, Positive Psychology at School: A School-Based Intervention to Promote Adolescents' Mental Health and Well-Being, Journal of Happiness Studies, 2014, 15, s. $1289-1311$. 


\section{Omówienie badań własnych}

$\mathrm{Na}$ potrzeby niniejszego artykułu autorzy przeprowadzili badania wśród 68 uczniów jednego z poznańskich gimnazjów. Celem badań było sprawdzenie hipotezy, że także na gruncie polskim można stwierdzić istnienie związku pomiędzy stylem atrybucji a ocenami z matematyki. Przedmiotem zainteresowań była także płeć dziecka, jako zmienna wpływająca na charakter stylu atrybucji dominującego u ucznia.

Badanie przeprowadzono od października 2014 do stycznia 2015 roku, w formie indywidualnej (uczeń vs osoba badająca), wśród uczniów szkoły gimnazjalnej w Poznaniu. Próba badawcza została określona losowo (dostępność uczniów) spośród uczniów klas II i III, których rodzice/ opiekunowie wyrazili zgodę pisemną. Próba objęła 68 osób w wieku od 14 do 17 lat, w tym 29 chłopców i 39 dziewczynek (tab. 2).

Tabela 2

Liczebność próby badawczej i podział liczbowy ze względu na płeć

\begin{tabular}{|l|c|c|}
\hline \multicolumn{1}{|c|}{ Płeć } & Liczebność & Procent \\
\hline Kobieta & 39 & 57,4 \\
\hline Mężczyzna & 29 & 42,6 \\
\hline Ogółem & 68 & 100,0 \\
\hline
\end{tabular}

Źródło: własne, wyniki statystyczne.

Rozkład liczbowy i procentowy uzyskanych ocen z matematyki w badanej próbie prezentuje tabela 3 .

Tabela 3

Ocena z matematyki

\begin{tabular}{|c|c|c|}
\hline Ocena z matematyki & Liczba uczniów & Procent uczniów \\
\hline 1 & 3 & 4,4 \\
\hline 2 & 25 & 36,8 \\
\hline 3 & 20 & 29,4 \\
\hline 4 & 13 & 19,1 \\
\hline 5 & 7 & 10,3 \\
\hline Ogółem & 68 & 100,0 \\
\hline
\end{tabular}

Źródło: własne, wyniki statystyczne. 
Do badania wykorzystano:

Kwestionariusz - test stylów atrybucji dla osób powyżej 7 roku życia (dzieci i młodzieży) Martina Seligmana - rodzaj testu papier-ołówek składający się $\mathrm{z} 48$ hipotetycznych wypowiedzi na temat pozytywnych i negatywnych wydarzeń, obejmujący wiele różnych sytuacji z życia, w tym szkolnych, dotyczących relacji rówieśniczych, więzi rodzinnych i zajęć pozalekcyjnych (zainteresowań). Uczniowie wybierali jedną odpowiedź najbardziej zbliżoną do swoich reakcji, zachowań w danej sytuacji.

Otrzymane wyniki opisano w trzech wymiarach: personalizacja, stałość i zasięg. W tabeli 4 wskazano m.in. średnie i odchylenie standardowe dla poszczególnych wymiarów dla zmiennej niezależnej - stylu atrybucji.

Tabela 4

Wyniki poszczególnych parametrów atrybucji (liczba badanych $\mathrm{n}=68$ )

\begin{tabular}{|l|c|c|c|c|}
\hline \multicolumn{1}{|c|}{ Zmienne } & Minimum & Maksimum & Średnia & Stand. odchylenia \\
\hline $\begin{array}{l}\text { Ocena } \\
\text { z matema- } \\
\text { tyki }\end{array}$ & 1 & 5 & 2,94 & 1,077 \\
\hline SN & 0 & 8 & 4,66 & 1,551 \\
\hline ZN & 0 & 8 & 3,22 & 1,735 \\
\hline PN & 0 & 8 & 3,62 & 1,612 \\
\hline N & 4 & 23 & 11,50 & 3,230 \\
\hline SP & 1 & 8 & 4,07 & 1,748 \\
\hline ZP & 0 & 8 & 4,57 & 1,577 \\
\hline PP & 2 & 8 & 4,38 & 1,246 \\
\hline P & 6 & 22 & 13,03 & 3,532 \\
\hline P-N & -10 & 13 & 1,53 & 4,885 \\
\hline
\end{tabular}

Źródło: własne, wyniki statystyczne.

Opis poszczególnych wymiarów i wyników:

- PN personalizacja niepowodzeń vs PP personalizacja powodzeń;

- SN stałość niepowodzeń vs SP stałość powodzeń;

- ZN zasięg niepowodzeń vs ZP zasięg powodzeń;

- P (wynik ogólny dla atrybucji powodzeń);

- N (wynik ogólny dla atrybucji niepowodzeń);

- Styl atrybucji na osi pesymizm-optymizm (P-N).

Ankietę z pytaniami dotyczącymi: oceny z matematyki za rok ukończony (w przypadku uczniów II klasy - ocena roczna z matematyki z I klasy i w przypadku uczniów III klasy - ocena roczna z matematyki z II klasy), płci ucznia i dodatkowo wykształcenia rodziców/opiekunów.

Hipotezy badawcze:

A

H0: Dominujący styl atrybucji nie koreluje z oceną z matematyki.

H1: Dominujący styl atrybucji koreluje z oceną z matematyki. 
Założenie: im bardziej pozytywny styl atrybucji, tym lepsze oceny szkolne z matematyki.

B

H0: Płeć nie koreluje z dominującym stylem atrybucji.

H1: Płeć koreluje z dominującym stylem atrybucji.

Założenie: Wyniki w teście do badania stylu atrybucji określające pesymizm częściej uzyskują dziewczęta, a wyniki w teście do badania stylu atrybucji określające optymizm uzyskują częściej chłopcy.

Zmienne dla hipotez A:

Styl atrybucji - zmienna niezależna; zmienna porządkowa.

Ocena z matematyki - zmienna zależna; zmienna ilorazowa.

Zmienne dla hipotez B:

Płeć - zmienna niezależna; zmienna nominalna.

Styl atrybucji - zmienna zależna; zmienna porządkowa.

Metody statystyczne - wybór testów statystycznych.

W celu sprawdzenia zależności między zmiennymi nominalnymi zastosowano test Chi 2. Zostały obliczone współczynniki kontyngencji Fi i V Cramera. Do badania korelacji pomiędzy zmiennymi porządkowymi i ilorazowymi zastosowano test $r$ Spearmana (badający zależności liniowe). Do obliczeń przyjęto poziom istotności alfa $=0,05$.

Zastosowanie testu r-Pearsona miało wskazać, czy istnieją zależności między zmienną porządkową i zmienną ilorazową oraz siłę związku pomiędzy nimi dla hipotezy A: styl atrybucji i ocena z matematyki (tab. 5).

Tabela 5

Wyniki z analizy statystycznej hipotez A

\begin{tabular}{|l|l|c|c|}
\hline \multicolumn{2}{|l|}{} & $\begin{array}{c}\text { Ocena } \\
\text { z matematyki }\end{array}$ & $\begin{array}{c}\text { P-N Wynik } \\
\text { ogólny }\end{array}$ \\
\hline \multirow{2}{*}{$\begin{array}{l}\text { Ocena z matema- } \\
\text { tyki }\end{array}$} & Korelacja Pearsona & 1 &, $297^{*}$ \\
\cline { 2 - 4 } & Ist. (dwustr.) & &, 014 \\
\cline { 2 - 4 } & I & 68 & 68 \\
\hline \multirow{2}{*}{ P-N Wynik ogólny } & Korelacja Pearsona &, $297^{*}$ & 1 \\
\cline { 2 - 4 } & Ist. (dwustr.) &, 014 & \\
\cline { 2 - 4 } & I & 68 & 68 \\
\hline
\end{tabular}

* - korelacja istotna na poziomie 0,05 (dwustr.)

Źródło: własne, wyniki statystyczne.

Z przeprowadzonych badań wynika, że występuje pomiędzy zmiennymi słaba korelacja dodatnia (tab. 5). Możemy zatem wnioskować o prawdziwości H1 (przy jednoczesnym odrzuceniu H0), że im wyższy poziom optymizmu (styl atrybucji), tym wyższa ocena z matematyki. 
Zastosowanie testu Chi 2 miało natomiast wskazać wystąpienie zależności między zmienną nominalną a porządkową - w hipotezie B: płeć i styl atrybucji. Wyniki tej analizy prezentują tabele 6 i 7.

Tabela 6

Wyniki dla Hipotez z grupy B - test chi-kwadrat

\begin{tabular}{|l|c|c|c|}
\hline & Wartość & df & $\begin{array}{c}\text { Asymp. ist. } \\
\text { (dwustronny) }\end{array}$ \\
\hline Chi-kwadrat Pearsona & $5,999 a$ & 4 &, 199 \\
\hline Iloraz wiarygodności przez & 6,745 & 4 &, 150 \\
\hline $\begin{array}{l}\text { Powiązanie liniowe } \\
\text { liniowe }\end{array}$ & 2,667 & 1 & \\
\hline N poprawnych obserwacji & 68 & & \\
\hline
\end{tabular}

a - liczebność oczekiwana dla komórek 3 (33,0\%) jest niższa niż 5. Minimalna liczebność oczekiwana to 2,13.

Źródło: własne, wyniki statystyczne.

Tabela 7

Miary symetryczne dla stylu atrybucji i płci

\begin{tabular}{|l|l|c|c|}
\hline \multicolumn{2}{|c|}{} & Wartość & $\begin{array}{c}\text { Przybliżona } \\
\text { istotność }\end{array}$ \\
\hline Nominalne przez nominalne & Fi &, 297 &, 199 \\
\cline { 2 - 4 } & V Cramera &, 297 &, 199 \\
\hline N poprawnych obserwacji & 68 & \\
\hline
\end{tabular}

Źródło: własne, wyniki statystyczne.

Na podstawie analizy statystycznej można stwierdzić, że nie udało się wykazać zależności pomiędzy zmiennymi z powodu zbyt małej liczebności próby (liczebność oczekiwana dla 3 komórek (33,0\%) jest niższa aniżeli 5). Można zatem odrzucić H1 w badaniach przeprowadzonych na próbie równej 68 badanych, a potwierdzić H0, która mówiła, że nie istnieje związek między płcią a stylem atrybucji. Analizując wyniki celem potwierdzenia lub odrzucenia hipotez z grupy B, uzyskano także porównanie wyników stylu atrybucji i liczby badanych z podziałem na płeć, co prezentuje tabela 8. Rozkład procentowy tego porównania prezentuje tabela 9. Porównanie to może być predykatorem kolejnych badań i prób potwierdzenia lub odrzucenia hipotez z grupy B, uwzględniających znacznie większą próbę badawczą, będącą próbą reprezentatywną dla populacji uczniów gimnazjum, zgodnie z założeniami statystycznymi. 
Wynik stylu atrybucji a liczba badanych z podziałem na płeć

\begin{tabular}{|l|l|c|c|}
\hline \multirow{2}{*}{ Styl atrybucji } & \multicolumn{2}{|c|}{ Płeć } \\
\cline { 3 - 4 } & \multirow{3}{*}{ P-N Wynik ogólny } & K & M \\
\cline { 2 - 4 } & $\begin{array}{l}\text { wielki pesymizm } \\
\text { umiarkowany pesy- } \\
\text { mizm }\end{array}$ & 14 & 13 \\
\cline { 2 - 4 } & wynik przeciętny & 8 & 5 \\
\cline { 2 - 4 } & $\begin{array}{l}\text { umiarkowany opty- } \\
\text { mizm }\end{array}$ & 8 & 9 \\
\cline { 2 - 4 } & wielki optymizm & 4 & 1 \\
\hline Ogółem & 39 & 29 \\
\hline
\end{tabular}

Źródło: własne, wyniki statystyczne.

Tabela 9

Procentowy rozkład wyników z podziałem na płeć w badanej próbie

\begin{tabular}{|l|l|c|c|}
\hline \multicolumn{2}{|c|}{ Styl atrybucji } & \multicolumn{2}{|c|}{ Płeć - \% } \\
\cline { 2 - 4 } & \multirow{3}{*}{ P-N Wynik ogólny } & K - \% & M - \% \\
\cline { 2 - 4 } & $\begin{array}{l}\text { wielki pesymizm } \\
\text { umiarkowany pesy- } \\
\text { mizm }\end{array}$ & 36 & 45 \\
\cline { 2 - 4 } & wynik przeciętny & 20,5 & 17 \\
\cline { 2 - 4 } & $\begin{array}{l}\text { umiarkowany opty- } \\
\text { mizm }\end{array}$ & 20,5 & 31 \\
\cline { 2 - 4 } & wielki optymizm & 10 & 3,05 \\
\hline Ogółem & 100 & 100 \\
\hline
\end{tabular}

Źródło: własne, wyniki statystyczne.

Na podstawie powyższych wyników można wnioskować o większej liczbie pesymistów (wielki i umiarkowany pesymista) wśród badanych chłopców, w stosunku do badanej próby dziewcząt. Natomiast, większy procent dziewcząt ma wynik: umiarkowany optymista i optymista w pełnej skali, względem wyników chłopców. Można go traktować tylko jako kierunek wnioskowania, mając na uwadze nierówność badanych prób (39 dziewcząt i 29 chłopców).

Analizując wyniki dla poszczególnych wymiarów stylu atrybucji, zauważono dodatnią zależność statystyczną pomiędzy zmiennymi ZN (zasięg niepowodzeń) a płcią, której wartość (miary asymptotyczne) wskazuje na istnienie nikłej zależności dodatniej między nimi, co wskazuje tabela 10 i 11. 
Tabela 10

Wyniki dla wymiaru ZN, a płeć - test chi-kwadrat

\begin{tabular}{|l|c|c|c|}
\hline & Wartość & $\mathrm{df}$ & $\begin{array}{c}\text { Asymp. ist. } \\
\text { (dwustronny) }\end{array}$ \\
\hline Chi-kwadrat Pearsona & $2,756^{\mathrm{a}}$ & 4 &, 600 \\
\hline Iloraz wiarygodności & 2,821 & 4 &, 588 \\
\hline $\begin{array}{l}\text { Powiązanie liniowe przez } \\
\text { liniowe }\end{array}$ &, 317 & 1 &, 573 \\
\hline N poprawnych obserwacji & 68 & & \\
\hline
\end{tabular}

a - liczebność oczekiwana dla komórek 2 (20,0\%) niższa aniżeli 5. Minimalna liczebność oczekiwana to ,85. Źródło: własne, wyniki statystyczne.

Tabela 11

Miary symetryczne dla ZN i płci

\begin{tabular}{|l|l|c|c|}
\hline \multicolumn{2}{|c|}{} & Wartość & Przybliż. ist. \\
\hline Nominalne przez nominalne & Fi &, 201 &, 600 \\
\cline { 2 - 4 } & V Cramera &, 201 &, 600 \\
\hline N poprawnych obserwacji & 68 & \\
\hline
\end{tabular}

Źródło: własne, wyniki statystyczne.

Liczebność uzyskanych wyników w teście Martina Seligmana w wymiarze ZN (Zasięg Niepowodzeń) pokazuje tabela 12.

Tabela 12

Liczebność uzyskanych wyników w wymiarze ZN z podziałem na płeć

\begin{tabular}{|l|l|c|c|}
\hline \multicolumn{2}{|c|}{ Styl atrybucji - wymiar ZN } & \multicolumn{2}{c|}{ Płeć } \\
\cline { 2 - 4 } & dziewczyna & chłopak \\
\hline ZN Zasięg niepowodzeń & wielki optymizm & 7 & 7 \\
\cline { 2 - 4 } & umiarkowany optymizm & 17 & 7 \\
\cline { 2 - 4 } & wynik przeciętny & 6 & 6 \\
\cline { 2 - 4 } & umiarkowanym pesymizm & 8 & 8 \\
\cline { 2 - 4 } & wielkim pesymizm & 1 & 1 \\
\hline Ogółem & 39 & 29 \\
\hline
\end{tabular}

Źródło: własne, wyniki statystyczne.

\section{Dyskusja}

Badanie będące fundamentem niniejszego artykułu należy potraktować jako pilotażowe. Grupa 68 uczniów z pewnością nie jest próbą reprezenta- 
tywną dla całej populacji gimnazjalistów, liczącej w Polsce ponad 1000000 osób ${ }^{16}$. Pomimo jednak ograniczonej liczby badanych udało się potwierdzić główną hipotezę artykułu o związku pomiędzy stylem atrybucji ucznia a jego ocenami z matematyki. Siła związku jest słaba, natomiast potwierdzenie związku stanowi dla autorów dowód na konieczność przeprowadzenia dalszych badań na reprezentatywnej próbie badawczej. Autorzy zakładają, że badanie przeprowadzone na reprezentatywnej próbie badawczej wykaże większą siłę związku pomiędzy zmiennymi.

W przypadku korelacji płci ze stylem atrybucji potwierdzona została hipoteza zerowa, jednakże wyniki w obszarze ZN (zasięg niepowodzeń) a płeć pokazuje ciekawą zależność - dziewczęta częściej osiągają tutaj wynik w wymiarze „umiarkowany optymizm" niż chłopcy. Należy w tym obszarze podkreślić istotny aspekt: jak wskazano w pierwszej części artykułu, wysokie wyniki $\mathrm{w}$ wymiarze $\mathrm{ZN}$ są niezwykle istotne dla procesów motywacyjnych ucznia ${ }^{17}$. Znaczące różnice w liczbie dziewcząt i chłopców uzyskujących wyniki typowe dla „umiarkowanego optymizmu” stanowią dla autorów potwierdzenie hipotezy Martina Seligmana, że do około 12 roku życiu dziewczynki są większymi optymistkami niż chłopcy ${ }^{18}$. Odwrócenie proporcji na niekorzyść dziewcząt następuje $\mathrm{w}$ wyniku zmiany $\mathrm{w}$ procesie komunikacji z nimi, związanej z procesami dojrzewania i w konsekwencji przypisywania dziewczętom coraz sztywniejszych ról społecznych. Warto jednak zauważyć, iż pomimo swojego pilotażowego charakteru badania ujawniły pewne prawidłowości w tym zakresie (dla wymiaru ZN).

Badania ujawniły także korelację pomiędzy wykształceniem matki a ocenami ucznia z matematyki. Hipoteza o związku wykształcenia matki a oceną $\mathrm{z}$ matematyki nie stanowiła punktu wyjścia dla projektowanych badań, jednak ze względu na siłę związku, jaka została potwierdzona w analizach statystycznych, zdaniem autorów, warto o niej napisać. Tabela 13 prezentuje wyniki w tym obszarze.

Korelacja pomiędzy wykształceniem matki a oceną z matematyki jest istotna na poziomie 0,01, co oznacza, że jest silniejsza od korelacji pomiędzy stylem atrybucji ucznia a oceną z matematyki. Jednocześnie badania wykazały, że nie istnieje żadna korelacja pomiędzy wykształceniem ojca a oceną z matematyki ucznia. Wyniki te wydają się niezwykle ciekawe, szczególnie w kontekście procesu uczenia się stylu atrybucji przez dzieci. Badania wskazują, że styl atrybucji matek związany z wydarzeniami negatywnymi jest

16 System Informacji Oświatowej, http://www.cie.men.gov.pl/index.php/danestatystyczne/137.html, [dostęp: 22.04.2014].

17 L.B. Alloy i in., Attributional Style, s. 681-687.

18 M.E.P. Seligman, Optymizmu można się nauczyć, s. 66. 
Tabela 13

Ocena z matematyki a wykształcenie matki

\begin{tabular}{|l|l|c|c|}
\hline \multicolumn{2}{|c|}{} & $\begin{array}{c}\text { Ocena } \\
\text { z matematyki }\end{array}$ & $\begin{array}{c}\text { Wykształcenie } \\
\text { matki }\end{array}$ \\
\hline \multirow{2}{*}{$\begin{array}{l}\text { Ocena z matema- } \\
\text { tyki }\end{array}$} & Korelacja Pearsona & 1 &, $325^{\text {** }}$ \\
\cline { 2 - 4 } & Ist. (dwustr.) & &, 007 \\
\cline { 2 - 4 } & I & 68 & 68 \\
\hline \multirow{2}{*}{$\begin{array}{l}\text { Wykształcenie } \\
\text { matki }\end{array}$} & Korelacja Pearsona &, $325^{* *}$ & 1 \\
\cline { 2 - 4 } & Ist. (dwustr.) &, 007 & 68 \\
\cline { 2 - 4 } & I & 68 & \\
\hline
\end{tabular}

** - korelacja istotna na poziomie 0.01 (dwustr.).

Źródło: własne, wyniki statystyczne.

skorelowany ze stylem atrybucji dzieci, natomiast styl atrybucji ojców nie ma związku ze stylem atrybucji dzieci ${ }^{19}$. Zgodnie $\mathrm{z}$ modelem uczenia się stylu atrybucji może to wynikać z faktu, iż kulturowo uwarunkowany proces wychowania opiera się głównie na komunikacji matka-dziecko i to matka właśnie jest w tym modelu "przekazicielką" stylu atrybucji. Analizując dostępne badania odnośnie wpływu stylu atrybucji na osiągnięcia szkolne można wysunąć hipotezę, iż matki z wyższym wykształceniem mają także bardziej optymistyczny styl atrybucji od tych z wykształceniem niższym (szczególnie jeśli chodzi o sposób wyjaśniania dzieciom przyczyn porażek/sukcesów szkolnych) i tym samym przekazują swym dzieciom bardziej optymistyczny styl atrybucji. Jest to jednak hipoteza wymagająca dalszych badań, pozwalających na zweryfikowanie zależności pomiędzy wykształceniem matek, ich stylem atrybucji oraz stylem atrybucji ich dzieci. Wydaje się ona jednak prawdopodobna, biorąc pod uwagę, że korelacja pomiędzy wykształceniem ojca a ocenami dziecka nie występuje w ogóle. Może to bowiem oznaczać, iż czynnikiem decydującym nie jest tutaj „dostępność wiedzy i umiejętności" (wówczas bowiem wykształcenie ojca również korelowałoby z ocenami dziecka) w systemie rodzinnym, ale bardziej aspekt komunikacyjny.

$\mathrm{Na}$ koniec warto zwrócić uwagę na jeszcze jeden aspekt przeprowadzonych badań. Ponad 39\% przebadanych uczniów otrzymało w teście wyniki plasujące je w kategorii „wielki pesymizm” (tab. 14), zaś średni wynik wynosił 1,53 punktów.

19 R.W. Brown, Social Psychology, Second Edition, New York 1986, s. 160. 
Styl atrybucji - wynik ogólny (P-N)

\begin{tabular}{|l|l|c|c|}
\hline \multicolumn{2}{|c|}{} & $\begin{array}{c}\text { Liczba } \\
\text { odpowiedzi }\end{array}$ & Procenty \\
\hline \multirow{4}{*}{ Ważne } & wielki pesymizm & 27 & 39,7 \\
\cline { 2 - 4 } & umiarkowany pesymizm & 10 & 14,7 \\
\cline { 2 - 4 } & wynik przeciętny & 17 & 25,0 \\
\cline { 2 - 4 } & umiarkowanym optymizm & 9 & 13,2 \\
\cline { 2 - 4 } & wielki optymizm & 5 & 7,4 \\
\cline { 2 - 4 } & Ogółem & 68 & 100,0 \\
\hline
\end{tabular}

Źródło: własne, wyniki statystyczne.

Abstrahując od kwestii korelacji stylu atrybucji z innymi czynnikami, warto podkreślić, że ponad $1 / 3$ przebadanych uczniów znajduje się $\mathrm{w}$ kategorii, która przez wielu badaczy uznawana jest za predykator przyszłej depresji20, co może być niepokojące w kontekście dużo szerszym niż tylko osiągnięcia w obszarze przedmiotów szkolnych.

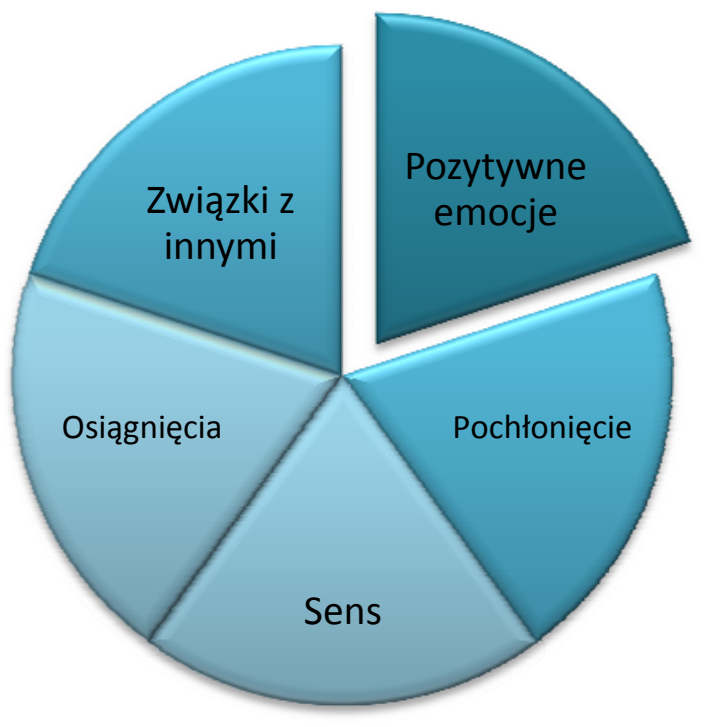

Ryc. 1. Model PERMA

(źródło: opracowanie własne na podstawie: http:/ / positivepsychologymelbourne.com.au/PERMA-model [dostęp: 27.04.2015])

${ }^{20}$ P.D. Sweeney, K. Anderson, S. Bailey, Attributional style in depression: A meta-analytic review, Journal of Personality and Social Psychology, 1986, 50(5), s. 974-991. 
Reasumując tę część dyskusji, można zauważyć dwie głównie prawidłowości: po pierwsze, wszelkie korelacje pomiędzy stylem atrybucji wymagają potwierdzenia na większej próbie badawczej gimnazjalistów, chociaż pewne prawidłowości są już zauważalne, po drugie zaś - pojawia się pytanie o poziom dobrostanu polskich uczniów i ich stan psychiczny? W kontekście właśnie tej drugiej kwestii warto zasygnalizować, na czym polega model wsparcia uczniów i nauczycieli projektowany przez Martina Seligmana i innych psychologów pozytywnych. Opiera się on na założeniu, iż efektywna szkoła powinna uczyć nie tylko wiedzy i umiejętności, ale także wspierać rozwój dobrostanu ucznia, opartego na pięciu filarach tzw. modelu PERMA. Prezentuje go rycina 1.

Na podstawie powyższego modelu skonstruowano szereg technik oraz interwencji pedagogicznych, wdrożenie których sprzyja podniesieniu odporności psychicznej uczniów oraz motywacji do aktywnego uczestnictwa w zajęciach. Opierają się one na kilku głównych założeniach ${ }^{21}$.

1. Budowaniu kompetencji społecznych uczniów, takich jak asertywność, umiejętność proszenia o pomoc, świadomość własnych procesów myślowych generujących emocje.

2. Podejściu systemowym, zakładającym, iż skuteczność działań „pozytywnych" uwarunkowana jest poziomem współpracy nauczycieli różnych przedmiotów z rodzicami. Jedna z zaprojektowanych metod polega na sporządzaniu przez uczniów nowego drzewa genealogicznego rodziny. Wyraża się ona tym, że uczniowie są proszeni o sporządzenie, we współpracy z rodzicami i przyjaciółmi, listy zalet członków swojej rodziny, które mogą być im pomocne $\mathrm{w}$ osiąganiu sukcesów szkolnych. Wzmacnia to poczucie oparcia społecznego, ale także, $\mathrm{w}$ rezultacie, może przyczynić się do zmiany "opowieści” o własnej rodzinie, na bardziej optymistyczną i rozwojową.

3. Zmianie akcentów $\mathrm{w}$ narracji nauczycieli stosowanej $\mathrm{w}$ trakcie zajęć. Jednym z przykładów mogą być dyskusje inicjowane przez nauczycieli prowadzących, $\mathrm{w}$ ramach których uczniowie odnoszą się do tematu rywalizacji, szukając jej zalet i uświadamiając sobie, że członek przeciwnej drużyny nie musi być postrzegany jako wróg, lecz jako źródło motywacji do „bycia lepszym".

4. Podnoszeniu świadomości nauczycieli na temat siły komunikacji i uczeniu ich porozumiewania się z uczniami w sposób kształtujący pozytywny styl atrybucji.

${ }^{21}$ M.E.P. Seligman i in., Positive education: positive psychology and classroom interventions, Oxford Review of Education, 2009, 35, 3, s. 293-311. 
5. Pozytywnej emocjonalności. Nauczycieli szkół elementarnych zachęca się, aby zaczynali lekcje od ćwiczenia pod nazwą "Zapisz trzy rzeczy, które poszły Ci wczoraj naprawdę dobrze i uzasadnij dlaczego?" Jego celem jest zmiana negatywnych przekonań na temat lekcji przy wykorzystaniu procesu uczenia się i warunkowania. Lekcja nie ma zaczynać się od schematycznego sprawdzania obecności oraz prac domowych (co u uczniów o negatywnym stylu atrybucji zwiększa poziom napięcia emocjonalnego i wzmacnia myślenie warunkowe według schematu: lekcja = stres), lecz od kierunkowania świadomości uczniów na ich sukcesy i tym samym poprawę nastroju na początku zajęć.

Badacze wskazują nie tylko na znaczenie psychologiczne technik psychologii pozytywnej, ale także na neurologiczne22, szczególnie związane z układem dopaminowym.

W niniejszej pracy przedstawiliśmy osiowe pojęcie psychologii pozytywnej (styl atrybucji), wyniki badań naukowych związanych zarówno $\mathrm{z}$ funkcjonowaniem uczniów $\mathrm{z}$ określonym stylem atrybucji $\mathrm{w}$ kontekście szkolnym, jak i skutecznością technik opartych na psychologii pozytywnej oraz ramowy zarys zasad kształcenia opartych na psychologii pozytywnej. O ile wyniki badań nad wpływem technik psychologii pozytywnej na psychologiczny dobrostan uczniów są jednorodne i wskazują na ich skuteczność, o tyle badania odnośnie znaczenia tych technik dla podniesienia ocen przedmiotowych wciąż trwają i nie ma podstaw, aby wyciągać już teraz jednoznaczne wnioski. Pojawia się zatem pytanie: Czy warto wdrażać zasady psychologii pozytywnej w polskich szkołach? W naszej opinii odpowiedź na to pytanie zależy od optyki przyjmowanej przez samych nauczycieli. Jeśli definiujemy cele kształcenia wyłącznie w kontekście przekazywania przez nauczycieli i nabywania przez uczniów wiedzy i umiejętności, pomiaru „twardych wskaźników”, w tym ocen uzyskiwanych przez uczniów, wówczas odpowiedź będzie odroczona $\mathrm{w}$ czasie, do momentu uzyskania jednoznacznych wyników badań empirycznych. Jeśli zaś istotny dla nas, jako nauczycieli, jest psychologiczny aspekt funkcjonowania uczniów w kontekstach szkolnych, psychologia pozytywna daje nam szereg narzędzi pomagających budować psychiczny dobrostan ucznia. Martin Seligman pytał rodziców, czego chcą dla swoich dzieci w przyszłości. Odpowiedzi brzmiały: „szczęścia”. „zdrowia”, "poczucia satysfakcji”, „dobrych relacji”, „radości”. Na pytanie zaś, czego uczy ich dzieci szkoła, ci sami rodzice odpowiadali: „ma-

22 Bardzo interesujący przegląd badań nad wpływem dopaminy na procesy uczenia się oraz motywacji odnaleźć można m.in. w: G. Pourtois, W. Notebaert, T. Verguts (red.), Cognitive and affective control, Frontiers in Psychology, 2013. 
tematyki”, „umiejętności”, „dyscypliny", „osiągania celów”23. Uderzające było, że obie listy wcale lub prawie wcale się nie pokrywały. Techniki psychologii pozytywnej pozwalają na komplementarne uzupełnianie się różnych wartości, właściwie bez ingerencji w programy nauczania czy uwarunkowania instytucjonalne. Aby jednak były stosowane skutecznie, konieczne jest przede wszystkim przekonanie nauczyciela, że warto i można je zastosować w szkole. W opinii autorów niniejszego tekstu byłoby to wskazane i rozwojowe, szczególnie $w$ kontekście budowania odporności psychicznej i dobrostanu przyszłych pokoleń.

\section{BIBLIOGRAFIA}

Abramson L.Y., Seligman M.E.P., Teasdale J.D., Learned Helplessness in Humans: Critique and Reformulation, Journal of Abnormal Psychology, 1978, 87, 1.

Alloy L.B., Abramson L.Y., Peterson C., Seligman M.E.P., Attributional Style and the Generality of Learned Helplessness, Journal of Personality and Social Psychology, 1984, 46, 3.

Brown R.W., Social Psychology, Second Edition, The Free Press, New York 1986.

Caimei L., Bates T.C., The structure of attributional style: Cognitive styles and optimism pessimism bias in the Attributional Style Questionnaire, Personality and Individual Differences, 2014, 66.

Chan S.M., Wong A.K.Y., Shyness in late childhood: relations with attributional styles and selfesteem, Child: Care, Health and Development, 2011, 39, 2.

Ciarrochi J., Heaven P.C.L., Davis F., The impact of hope, self-esteem, and attributional style on adolescents' school grades and emotional well-being: A longitudinal study, Journal of Research in Personality, 2007, 41.

Gordon R.A., Attributional style and athletic performance: Strategic optimism and defensive pessimism, Psychology of Sport and Exercise, 2008, 9.

Dobson K.S., Dozois D.J.A., Historical and Philosophical Bases of the Cognitive-Behavioral Therapy, [w:] Handbook of Cognitve-Behavioral Therapies, red. K.S. Dobson, The Guilford Press, New York 2010.

Oxford R.L., Cuéllar L., Positive psychology in cross-cultural narratives: Mexican students discover themselves while learning Chinese, Studies in Second Language Learning and Teaching, 2014, 4(2).

Seligman M.E.P., Optymizmu można się nauczyć. Jak zmienić swoje myślenia $i$ swoje życie, przekł. Andrzej Jankowski, Wydawnictwo Media Rodzina, Poznań 2002.

Seligman M.E.P., Ernstb R.M., Gillhamc J., Reivicha K., Linkins M., Positive education: positive psychology and classroom interventions, Oxford Review of Education, 2009, 35, 3.

Shaghaghy F., Saffarinia M., Iranpoor M., Soltanynejad A., The Relationship of Early Maladaptive Schemas, Attributional Styles and Learned Helplessness among Addicted and NonAddicted Men, Addict \& Health, 2011, 3(1-2).

Shoshani A., Steinmetz S., Positive Psychology at School: A School-Based Intervention to Promote Adolescents' Mental Health and Well-Being, Journal of Happiness Studies, 2014, 15.

${ }^{23}$ M.E.P. Seligman i in., Positive education, s. 1. 
Sweeney P.D., Anderson K., Bailey S., Attributional style in depression: A meta-analytic review, Journal of Personality and Social Psychology, 1986, 50(5).

Yates S.M., The Influence of Optimism and Pessimism on Student Achievement in Mathematics, Mathematics Education Research Journal, 2002, 14, 1.

Vella-Brodrick D.A., Rickard N.S., Chin T.C., An Evaluation of Positive Education at Geelong Grammar School: A Snapshot of 2013, The University of Melbourne, VIC, Melbourne 2014.

Pourtois G., Notebaert W., Verguts T. (red.), Cognitive and affective control, Frontiers in Psychology, February 2013.

System Informacji Oświatowej, http://www.cie.men.gov.pl/index.php/danestatystyczne/ 137.html, [dostęp: 22.04.2014].

The PERMA model, http://positivepsychologymelbourne.com.au/PERMA-model, [dostęp: 27.04.2015]. 